\title{
Analisis Belanja Daerah Pemerintah Provinsi Jambi
}

\author{
Fathiyah $^{1,4 *}$, Abdi Sukmana ${ }^{2}$, Hamid Majid ${ }^{3}$, Masnun $^{4}$ \\ 1,4 Fakultas Ekonomi Universitas Batanghari \\ 2,3, BPSDM Provinsi Jambi \\ *Correspondence email: fathiyahzaky74@gmail.com, Hamid.majid6@gmail.com
}

\begin{abstract}
The purpose of this research is to analyze the efficiency of regional spending in Jambi provincial government. The research method used is descriptive and the analytical tools used in this study are the ratio of spending variance, the ratio of expenditure harmony and the ratio of spending efficiency. The data used in this study is secondary data in the form of budget realization report on the regional financial report of Jambi provincial government for the period 2015 - 2019. The results of this study concluded that the efficiency of spending in Jambi province based on the ratio of spending variance showed an average result of 91.41 meaning that the realization is smaller than the budgeted amount with the preferred difference category (favourable variance), while in the ratio of expenditure harmony based on the ratio of operating expenditure to total expenditure over the last five years shows an average yield of $74.27 \%$ and the ratio of capital expenditure to total expenditure on average of $25.72 \%$, meaning the proportion of operating expenditure allocation is greater than the proportion of capital expenditures, and the next based on the results of the calculation of the ratio of efficiency of expenditure obtained results of $91.41 \%$ with the category of efficient performance. This means that the Jambi Provincial Government is able to save and efficiently in conducting regional expenditure.
\end{abstract}

Keywords : Regional spending efficiency, Variance ratio, Harmony ratio, and expenditure efficiency ratio

Abstrak. Tujuan Penelitian ini adalah untuk menganalisis Efisiensi belanja daerah pada Pemerintah Provinsi Jambi. Metode Penelitian yang digunakan adalah deskriptif kuatitatif dan alat analisis yang gunakan dalam penelitian ini adalah rasio varians belanja, rasio keserasian belanja dan rasio efisiensi belanja. Adapun data yang digunakan dalam penelitian ini adalah data sekunder berupa laporan realisasi anggaran pada laporan keuangan daerah Pemerintah Provinsi Jambi periode 2015-2019. Hasil penelitian ini menyimpulkan bahwa efisiensi belanja daerah Provinsi jambi berdasarkan rasio varians belanja menunjukkan hasil rata-rata sebesar 91,41 artinya realisasinya lebih kecil dari jumlah yang dianggarkan dengan kategori selisih disukai (favourable variance), sedangkan pada rasio keserasian belanja berdasarkan rasio belanja operasi terhadap total belanja selama lima tahun terakhir menunjukkan hasil rata-rata $74,27 \%$ dan rasio belanja modal terhadap total belanja rata-rata sebesar $25,72 \%$, artinya proporsi alokasi belanja operasi lebih besar dari proporsi belanja modal, dan yang terakhir Berdasarkan hasil perhitungan rasio efisiensi belanja diperoleh hasil sebesar 91,41\% dengan kategori kinerjanya efisien. Artinya Pemerintah Provinsi Jambi mampu dalam menghemat dan efisien dalam melakukan belanja daerah.

Kata Kunci : Efisiensi belanja daerah, Rasio varians, Rasio keserasian, dan rasio efisiensi belanja

\section{Pendahuluan}

Pelaksanaan Otonomi daerah berdasarkan Undang-undang Nomor 32 tahun 2004 yang kemudian direvisi dengan Undang-undang Nomor 23 Tahun 2014 Tentang pemerintah daerah diwujudkan dalam pemberian wewenang kepada daerah untuk mengatur dan mengurus sendiri pemerintahan dan kepentingan masyarakatnya. Otonomi daerah pada bidang Pemerintahan selalu diikuti dengan otonomi dalam bidang keuangan atau desentralisasi fiskal, dengan diterbitkannya Undang-undang Nomor 33 tahun 2004 tentang perimbangan Keuangan antara Pemerintah Pusat dan Daerah, maka Daerah diberi kewenangan untuk menggali pendapatan dan melakukan peran alokasi pada Anggaran Pendapatan dan Belanja Daerah secara mandiri dalam menetapkan prioritas pembangunan daerahnya. Anggaran Pendapatan dan Belanja Daerah yang ditetapkan setiap tahun oleh Pemerintah daerah merupakan alat utama untuk melaksanakan pembangunan daerah, dimana untuk pembiayaan pelaksanaan pembangunan tersebut tercermin dari alokasi besarnya pendapatan dan belanja daerah. Jika alokasi Pendapatannya daerahnya besar maka secara otomatis alokasi pembiayaan pembangunan dalam Belanja daerah juga menjadi besar sehingga prioritas pembangunan derah dapat terlakasana dengan baik dan lancar.

Pembiayaan prioritas pembangunan yang dialokasikan pada belanja daerah seharusnya bisa digunakan secara ekonomis, efisien dan efektif, mengingat dengan adanya desentralisasi fiskal maka keuangan pemerintah daerah sangat terbatas serta mengurangi ketergantungan dengan bantuan pemerintah pusat. Agar pengelolaan belanja daerah dapat berjalan baik, lancar dan efisien maka perlu dilakukan pengukuran kinerja keuangan yang bertujuan untuk mengetahui kemampuan pemerintah daerah dalam membelanjakan uang publik apakah sudah secara efisien, efektif dan ekonomis (Mardiasmo, 2004). Menurut Mahmudi (2010) analisis belanja digunakan untuk mengukur sejauh mana pemerintah daerah sudah melakukan efisiensi anggaran, menghindari pengeluaran yang tidak tepat sasaran. Penelitian yang terkait dengan analisis belanja daerah pernah dilakukan oleh Suhaedi (2019) di Kabupaten Lombok Barat yang 
menyimpulkan hasil bahwa Varians belanja pada Kabupaten Lombok barat dalam kategori Favourable varians dan sebagian besar belanja daerah dialokasikan untuk belanja operasi baru kemudian belanja modal, sedangkan dari sisi pengelolaan anggaran juga masih kurang efisien. Tujuan dari penelitian ini sama dengan penelitian tersebut diatas dan yang membedakan dari penelitian sebelumnya adalah lokasi tempat penelitian dan tahun penelitan yang berbeda.

\section{Tinjauan Pustaka}

\section{Anggaran Pendapatan dan Belanja Daerah (APBD)}

APBD adalah kerangka keuangan tahunan daerah yang disepakati bersama oleh DPRD dengan pemerintah, yang intinya menggambarkan sumber-sumber pendapatan daerah, berapa alokasi pengeluaran untuk melaksanakan program/kegiatan, dan pembiayaan yang muncul saat surplus atau difisit (Direktorat Jenderal Perimbangan Keuangan (Kemenkeu, 2014). Sementara menurut Ramadani (2017), APBD dapat didefenisikan sebagai rencana keuangan pemerintah daerah yang mendeskripsikan mengenai perkiraan pengeluaran yang sebesar-besarnya dalam belanja kegiatan dan proyek daerah dalam satu tahun, serta juga dapat menggambarkan mengenai estimasi pendapatan dan sumber pendapatan daerah yang digunakan untuk menutupi biaya yang dimaksud. APBD terdiri atas anggran pendapatan, anggaran belanja, dan pembiayaan (Dharmawati \& Irmadaroyani, 2016). Laporan Realisasi Anggaran Menurut Mahsun dkk (2011) adalah laporan yang berisi tentang informasi mengenai pendapatan, belanja dan pembiayaan dari suatu entitas yang dibandingkan dengan anggaran ketiga pos tersebut.

\section{Belanja Daerah}

Belanja daerah (Lontaan dkk, 2016) merupakan beban pengeluaran daerah yang dialokasikan secara adil dan merata agar relatif dapat dinikmati oleh seluruh kelompok masyarakat tanpa diskriminasi, khususnya dalam pemberian pelayanan umum. Selanjutnya Zebua (2014) menyatakan belanja daerah teralokasi secara tepat ke pos-pos belanja yang dibutuhkan oleh masyarakat akan mendorong pertumbuhan yang positif dalam upaya peningkatan kesejahteraan masyarakat. Analisis belanja daerah dilakukan untuk mengevaluasi apakah pemerintah daerah telah menggunakan Anggaran Pendapatan dan Belanja Daerah (APBD) secara ekonomis, efisien dan efektif. Belanja daerah berdasarkan SAP (PP No.71 Tahun 2010), belanja diklasifikasikan menurut klasifikasi ekonomi (jenis belanja) dan fungsi. Penjelasan lebih lanjut untuk setiap klasifikasi diuraikan sebagai berikut :

1) Klasifikasi Ekonomi, adalah pengelompokan belanja yang didasarkan pada jenis belanja untuk melaksanakan suatu aktivitas, klasifikasi ekonomi untuk pemerintah pusat yaitu belanja pegawai, belanja barang, belanja modal, bunga, subsidi, hibah, bantuan sosial, dan belanja lain-lain. Klasifikasi ekonomi untuk pemerintah daerah meliputi belanja pegawai, belanja barang, belanja modal, bunga, subsidi, hibah, bantuan sosial, dan bantuan tak terduga.

2) Klasifikasi menurut Organisasi Publik, yaitu klasifikasi berdasarkan unit organisasi pengguna anggaran. Hal ini berarti bahwa belanja daerah disusun berdasarkan Satuan Kerja Perangkat Daerah yang bertindak sebagai pusat pertanggungjawaban uang/barang.

3) Klasifikasi Fungsi, adalah klasifikasi yang didasarkan pada fungsi-fungsi utama pemerintah pusat/daerah dalam memberikan pelayanan kepada masyarakat.

\section{Kinerja Keuangan Daerah}

Sartika (2019) menyatakan bahwa kinerja keuangan daerah merupakan suatu ukuran kinerja yang menggunakan indikator keuangan daerah. Salah satu alat untuk menilai kinerja keuangan daerah adalah dengan melakukan analisis rasio keuangan daerah. Melalui analisis rasio ini kita dapat mengukur dan menilai akuntabilitas keuangan daerah. Akuntabilitas tidak hanya diukur dari berapa jumlah uang publik digunakan untuk belanja, tetapi bagaimana uang tersebut dibelanjakan secara efisien, efektif dan ekonomis.

\section{Analisis Belanja Daerah}

Analisis belanja daerah sangat penting dilakukan untuk mengevaluasi apakah pemerintah telah menggunakan APBD secara ekonomis, efisien dan efektif. Mahmudi (2010) menyatakan bahwa analisis belanja daerah digunakan untuk melihat sejauh mana pemerintah daerah telah melakukan efisiensi anggaran, menghindari pengeluaran yang tidak perlu dan pengeluaran yang tidak tepat sasaran. Berdasarkan laporan Realisasi Anggaran analisis belanja daerah dapat dilakukan dengan menghitung analisis varians belanja, Rasio keserasian dan rasio efisiensi belanja.

\section{Rasio Varians Belanja}

Analisis ini dilakukan dengan cara menghitung selisih realisasi pendapatan dengan yang dianggarkan. Biasanya selisih anggaran sudah diinformasikan dalam laporan realisasi anggaran yang sudah disajikan oleh pemerintah daerah. Informasi selisih anggaran tersbut sangat membantu pengguna laporan dalam memahami dan menganalisis kinerja pendapatan (Saputra dkk, 2016), adapun formula dalam menghitung varians belanja adalah ; 
Varians Belanja $=\frac{\text { Realisasi Belanja Tahun } \mathrm{t}}{\text { Anggran Belanja Tahun } \mathrm{t}} \times 100 \%$

Selisih anggaran dokategorikan menjadi dua jenis yaitu (Mahmudi, 2016 )

1. Selisih disukai (favourable Variance) yang mengindikasikan bahwa realisasi anggaran lebih kecil dari anggarannya

2. Selisih tidak disukai (unfavourable Variance) yang mengindikasikan bahwa belanja lebih besar dari anggarannya.

\section{Rasio Keserasian Belanja}

Rasio keserasian yang membahas mengenai belanja operasi, dimana rasio ini merupakan perbandingan dari total biaya operasional dan pengeluaran daerah. Hubungan ini dimaksudkan untuk menginformasikan kepada setiap pengguna atau pihak yang berkepentingan mengenai laporan tentang bagian-bagian pengeluaran daerah yang didistribusikan untuk pengeluaran operasional. Belanja operasional sendiri merupakan jenis belanja yang kebermanfaatannya dirasakan dalam kurun waktu satu tahun keuangan. Sehingga hal tersebut bersifat jangka pendek dan pada beberapa kasus dapat berjalan secara kontinu dan konsisten (Farida, dkk, 2019). Umumnya proporsi belanja operasi selalu mendominasi dari seluruh total belanja daerah yaitu sebesar 60 - 90 persen. Berikut ini merupakan rumus dari rasio balanja operasi

Rasio Belanja Operasi $=\frac{\text { Realisasi Total Belanja Operasi }}{\text { Total Belanja }}$

Rasio belanja modal sendiri merupakan komparasi antara jumlah keseluruhan belanja modal yang terealisasi dengan jumlah keseluruhan belanja daerah. Berdasarkan pada tipe rasio ini, setiap pengguna laporan dapat melihat dengan jelas bagian dari pengeluaran daerah yang diperuntukkan untuk investasi dalam bentuk belanja modal pada tahun anggaran yang bersangkutan. Mahmudi (2016) menyatakan bahwa proporsi belanja modal terhadap total belanja daerah adalah 5-20 persen. Rasio belanja modal ini dirumuskan sebagai berikut :

Rasio Belanja Modal $=\frac{\text { Realisasi Total Belanja Modal }}{\text { Total Belanja }}$

\section{Rasio Efisiensi Belanja}

Mahmudi (2010) Rasio efisiensi belanja merupakan perbandingan antara realisasi belanja dengan anggaran belanja. Rasio efisiensi belanja ini digunakan untuk mengukur tingkat penghematan anggaran yang dilakukan pemerintah. Angka yang dihasilkan dari rasio efisiensi ini tidak bersifat absolut tetapi relatif, artinya tidak ada standar baku yang dianggap baik untuk rasio ini. Pemerintah daerah dinilai telah melakukan efisiensi anggaran jika rasio efisiennya kurang dari $100 \%$, sebaliknya jika lebih maka mengidentifikasikan telah terjadi pemborosan anggaran.

Rasio Efisiensi Belanja $=\frac{\text { Realisasi Belanja Daerah }}{\text { Anggran Belanja }}$ X 100\%

\section{Metode}

Teknik analisis yang gunakan dalam penelitian ini adalah deskriptif kuantitatif, dengan Jenis dan sumber data yang digunakan dalam penelitian ini adalah data sekunder yang diperoleh dari Laporan Keuangan Pemerintah Provinsi Jambi dalam bentuk Laporan Realisasi Anggaran di Badan Keuangan Daerah Provinsi Jambi. Disamping itu ada tambahan referensi dari penelitian dan jurnal-jurnal sebelumnya. Kemudian data tersebut diolah dengan menggunakan formula yang sudah disajikan sebelumnya serta dianalisis dengan menggunakan rasio varians belanja, rasio keserasian belanja dan rasio efisiensi belanja daerah.

\section{Hasil}

\section{Analisis Rasio Varians Belanja}


Tabel 1.

Rasio Varians Belanja Pemerintah Provinsi Jambi

\begin{tabular}{lcccl}
\hline \multicolumn{1}{c}{ Tahun } & Anggaran & Realisasi & \% & Kinerja \\
\hline 2015 & 3.039 .172 .287 .679 & 2.838 .721 .753 .215 & 93,40 & Favourable Variance \\
2016 & 3.102 .331 .335 .892 & 2.893 .449 .001 .005 & 93,27 & Favourable Variance \\
2017 & 3.794 .592 .677 .837 & 3.457 .094 .021 .644 & 91,11 & Favourable Variance \\
2018 & 3.944 .637 .398 .183 & 3.518 .360 .175 .187 & 89,19 & Favourable Variance \\
2019 & 4.338 .583 .747 .877 & 3.946 .292 .724 .212 & 90,96 & Favourable Variance \\
Rata-rata & 3.643 .863 .489 .493 & 3.330 .783 .535 .052 & 91,41 & Favourable Variance \\
\hline
\end{tabular}

Sumber : Bakeuda Provinsi Jambi, LRA Tahun 2015 - 2019. Data diolah.

Berdasarkan hasil analisis pada tabel 1 diatas dapat disimpulkan bahwa selama periode lima tahun terakhir rata-rata rasio varian belanja Pemerintah Provinsi Jambi sebesar 94.40\% dan termasuk dalam kategori selisih disukai (Favourable variance) karena realisasi belanja tidak melebihi jumlah yang dianggarkan, artinya Pemerintah Provinsi Jambi telah melakukan penghematan dan efisiensi dalam belanja daerah. Hal ini sejalan dengan penelitian yang dilakukan oleh Saputra dkk (2016) di Kabupaten Jembrana yang menyimpulkan hasil penelitiannya bahwa rata-rata rasio varians belanja Kabupaten Jembrana periode 2010 - 2014 sebesar 89,44\% dan dalam kategori baik.

\section{Analisis Rasio Keserasian Belanja \\ Rasio Belanja Operasi terhadap Total Belanja}

Tabel 2.

Rasio Belanja Operasi Terhadap Total Belanja Pemerintah Provinsi Jambi

\begin{tabular}{lrrr}
\hline \multicolumn{1}{c}{ Tahun } & Anggaran & Realisasi & \% \\
\hline 2015 & 2.046 .188 .302 .840 & 2.838 .721 .753 .215 & 72.08 \\
2016 & 1.947 .816 .538 .589 & 2.893 .449 .001 .005 & 67.32 \\
2017 & 2.561 .387 .667 .331 & 3.457 .094 .021 .644 & 74.09 \\
2018 & 2.733 .539 .585 .386 & 3.518 .360 .175 .187 & 77.69 \\
2019 & 3.079 .700 .724 .870 & 3.946 .292 .724 .212 & 78.04 \\
Rata-rata & 2.473 .726 .563 .803 & 3.330 .783 .535 .052 & \\
\hline
\end{tabular}

Sumber : Bakeuda Provinsi Jambi, LRA Tahun 2015 - 2019. Data diolah.

Berdasarkan hasil analisis pada table 2 diatas dapat disimpulkan bahwa dalam periode lima tahun terakhir rata-rata rasio belanja operasi terhadap total belanja adalah sebesar 74,27\%. hal ini menunjukkan bahwa hampir 75\% belanja daerah digunakan untuk belanja operasi, dan alokasi yang paling besar pada belanja pegawai serta belanja hibah. Sejalan dengan penelitian yang dilakukan oleh Sartika (2019) di Kabupaten Kepulauan Meranti yang menyimpulkan hasil penelitiannya bahwa rata-rata rasio Belanja operasi terhadap total belanja di Kabupaten Kepulauan Meranti periode 2012 - 2016 sebesar 74, 14\%.

\section{Rasio Belanja Modal terhadap Total Belanja}

Tabel 3.

Rasio Belanja Modal Terhadap Total Belanja Pemerintah Provinsi Jambi

\begin{tabular}{lrrr}
\hline \multicolumn{1}{c}{ Tahun } & Anggaran & Realisasi & \% \\
\hline 2015 & 791.487 .340 .374 & 2.838 .721 .753 .215 & 27.88 \\
2016 & 945.539 .006 .404 & 2.893 .449 .001 .005 & 32.68 \\
2017 & 895.648 .009 .332 & 3.457 .094 .021 .644 & 25.91 \\
2018 & 784.723 .907 .609 & 3.518 .360 .175 .187 & 22.30 \\
2019 & 866.500 .805 .931 & 3.946 .292 .724 .212 & 21.96 \\
Rata-rata & 856.779 .813 .930 & 3.330 .783 .535 .052 & \\
\hline
\end{tabular}

Sumber : Bakeuda Provinsi Jambi, LRA Tahun 2015 - 2019. Data diolah.

Berdasarkan hasil analisis pada tabel 3 dapat disimpulkan bahwa dalam periode lima tahun terakhir rata-rata alokasi belanja modal terhadap total belanja adalah sebesar $25.72 \%$ jauh dibawah proporsi belanja operasi, bagian terbesar dari belanja modal digunakan untuk belanja jalan, irigasi dan jaringan. Penelitian yang dilakukan oleh Farida dkk (2019) di Kabupaten Subang yang menyimpulkan hasil penelitiannya bahwa rata-rata rasio Belanja modal terhadap total belanja di Kabupaten Subang periode 2014 - 2017 sebesar 21,75\%. 


\section{Analisis Rasio Efisiensi Belanja}

Tabel 4.

Rasio Belanja Efisiensi Belanja Pemerintah Provinsi Jambi

\begin{tabular}{lrrrl}
\hline Tahun & Anggaran & Realisasi & \% & Kinerja \\
\hline 2015 & 2.838 .721 .753 .215 & 3.039 .172 .287 .679 & 93.40 & Efisien \\
2016 & 2.893 .449 .001 .005 & 3.102331 .335 .892 & 93.27 & Efisien \\
2017 & 3.457 .094 .021 .644 & 3.794 .592 .677 .837 & 91.11 & Efisien \\
2018 & 3.518 .360 .175 .187 & 3.944 .637 .398 .183 & 89.19 & Efisien \\
2019 & 3.946 .292 .724 .212 & 4.338 .583 .747 .877 & 90.96 & Efisien \\
Rata-rata & 3.330 .783 .535 .052 & 3.643 .863 .489 .493 & 91.41 & Efisien \\
\hline
\end{tabular}

Sumber : Bakeuda Provinsi Jambi, LRA Tahun 2015 - 2019. Data diolah.

Berdasarkan hasil analisis pada table 4 dapat disimpulkan bahwa dalam periode lima tahun terakhir rata-rata efisiensi belanja Pemerintah Provinsi Jambi sebesar 91,41\% dengan kategori kinerjanya efisien. Artinya Pemerintah Provinsi Jambi mampu untuk menghemat dan efisien dalam belanja, namun perlu untuk menjadi perhatian bahwa nilai sebesar $91,41 \%$ diatas belum tentu seluruhnya efisiensi dari belanja tetapi mungkin saja ada program dan kegiatan pada tahun-tahun tersebut tidak bisa diilaksanakan sehingga belanja daerah tidak bisa terealisir sebesar $100 \%$. Sejalan dengan penelitian yang dilakukan oleh Lontaan dkk (2016) di Kabupaten Minahasa Tahun 2012 - 2014 yang menyimpulkan hasil penelitiannya sebesar $91.60 \%$, artinya terjadi efisiensi penggunaan anggaran pada Pemerintah Kabupaten Minahasa.

\section{Simpulan}

Berdasarkan hasil penelitian dan pembahasan mengenai analisis belanja daerah Pemerintah Provinsi Jambi , maka diperoleh kesimpulan sebagai berikut :

1. Analisis rasio varians belanja dengan rata-rata besarnya varians selama tahun 2015 -2019 sebesar 91,41\% dengan kategori kinerja favourable variance atau selisih yang disukai karena realisasi belanja lebih kecil dari jumlah yang dianggarkan

2. Analisis Rasio keserasian Belanja yang dihitung dari rasio belanja operasi terhadapi total belanja menunjukkan hasil rata-rata selama tahun 2015 - 2019 sebesar 74,27\%, artinya lebih dari separuh belanja daerah digunakan untuk belanja operasi. Sedangkan rasio belanja modal terhadap total belanja menunjukkan hasil sebesar 25,72\%, nilainya jauh dibawah proporsi belanja operasi dan bagian terbesar dari belanja modal ini adalah untuk belanja jalan, irigasi dan jaringan

3. Analisis rasio Efisiensi belanja selama tahun 2015 - 2019 menunjukkan hasil rata-rata sebesar $91,41 \%$ dengan kategori kinerja efisien, artinya pemerintah Provinsi Jambi mampu menghemat dan efisien dalam menggunakan belanja daerah.

\section{Daftar Pustaka}

Farida, Ali Siti Raden Faisal Maulana Nugraha, Analisis Laporan Keuangan Pemerintah Daerah Kabupaten Subang, Publica : Jurnal Pemikiran Administrasi Negara, Volume 11, Nomor 2, Desember 2019, 107 - 124. Administrasi Publik Fakultas Ilmu Sosial dan Ilmu Politik UIN Sunan Gunung Djati Bandung. . DOI : https://doi.org/10.155575/jpan.v11i2.7644.

Lontaan, Indran Christian, Sonny Pangerapan, 2016, Analisis Belanja Daerah pada Pemerintah Kabupaten Minahasa Tahun Anggaran 2012 - 2014, Jurnal EMBA, Volume 4 Nomor 1 Maret 2015, Hal. 898-906. DOI : https://doi.org/1035794/emba.v4i1.11820

Ramadhani, Febby Randria. Analisis Kemandirian dan Efektivitas Keuangan Daerah di Kota tarakan Tahun 2010 2015, JEP, Volume 14 Nomor 1 Tahun 2016, Fakultas Ekonomi dan Bisnis, Universitas Muhammadiyah Malang. DOI : https://doi.org/10.22219/jep.v15i.3846.

Saputra, Sandy Candra. I Wayan Suwendra, Fridayana Yudiaat Maja. Analisis Kinerja Keuangan Pemerintah Daerah Dalam Pengelolaan Anggaran Pendapatan dan Belanja Daerah di Kabupaten Jembrana Tahun 2010 - 2014, $e$ Journal Bisma Universitas Pendidikan Ganesha Volume 4 Tahun 2016. Universitas Pendidikan Ganesha, Singaraja Indonesia.

Sartika, Novira. Analisis Rasio Keuangan Daerah Untuk Menilai Kinerja Keuangan Pemerintah Daerah Kepulauan Meranti. INOVBIZ : Jurnal Inovasi Bisnis 7 (2019), 147-153, Dec 2019, Politeknik Negeri Bengkalis, Riau 28711. DOI : 10.35314/inovbiz.v7i2.1207.

Suhaedi, Wirawan, Analisis Belanja Daerah, Jurnal Riset Akuntansi Aksioma,Volume 18 Nomor 2, Desember 2019. DOI : https://doi.org/10.29303/aksioma.v18i2.82 
Zebua, Wilman Forgatti, 2014, Pengaruh Alokasi belanja Modal, Belanja Barang dan Jasa, Belanja Hibah dan Belanja Bantuan Sosial terhadap Kualitas Pembangunan Manusia (Studi pada Kabupaten dan Kota Wilayah Provinsi Jawa Barat Thun 2011 - 2013), Jurnal Ilmiah Mahasiswa Volume 3 Nomor 1 Fakultas Ekonomi dan Bisnis, Universitas Brawijaya

Dharmawati, M.K dan Irmadariyani,R, 2016, Analisis Rasio Keuangan Anggaran Pendapatan dan Belanja Daerah Dalam menilai Kinerja Keuangan Pemerintah Daerah kabupaten Bayuwangi, Artikel ilmiah Mahasiswa, Jurusan akuntansi Fakultas Ekonomi Universitas Jember

Mahmudi, 2010. Analisis Laporan Keuangan Pemerintah Daerah Yogyakarta UPP AMP YPKN

Mahmudi, 2016. Analisis Laporan Keuangan Pemerintah Daerah Yogyakarta UPP AMP YPKN

Mahsun,M, 2011, Akuntansi Sektor Publik Edisi Ketiga, BPFE Yogyakarta

Mahsun, M, 2016, Pengukuran Kinerja Sektor Publik, BPFE, Yogyakarta

Mardiasmo, 2004, Akuntansi Sektor Publik (Edisi Kedua), Andi, Yogyakarta

Direktorat jenderal Perimbangan Keuangan Kementerian Keuangan (KEMENKEU), Deskripsi dan Analisis APBD Tahun 2014.

Pemerintah Provinsi Jambi, Laporan Keuangan Daerah Pemerintah Provinsi Jambi: Laporan Realisasi Anggaran dan Neraca Tahun 2015 -2019

Peraturan Pemerintah Nomor 71 Tahun 2010 tentang standar Akuntansi Pemerintahan

Undang-undang Nomor 32 Tahun 2004 tentang Pemerintah Daerah

Undang-undang Nomor 33 Tahun 2004 tentang Perimbangan Keuangan Antara Pemerintah Pusat dan Pemerintah Daerah

Undang-undang Nomor 23 Tahun 2014 tentang Pemerintah Daerah 